\title{
KOREAN ORTHOGRAPHY OF LOANWORDS AND SPELLING PROBLEMS WITH PROPER NOUNS FROM SLOVENIA
}

\author{
Minyoung CHANG \\ University of Ljubljana \\ oddmonica@gmail.com \\ Chikako SHIGEMORI BUČAR \\ University of Ljubljana \\ Chikako.bucar@guest.arnes.si
}

\begin{abstract}
This paper firstly introduces The Korean Orthography of Loanwords and its history. Recently with more cultural and economic exchanges between Korea and Slovenia, the Korean Orthography guidelines for Slovene words are needed to guide words of Slovene origin when settling in Korean. Although Serbo-Croatian is not an official language of Slovenia, some Slovene words are currently written in Korean according to the guidelines for Serbo-Croatian in KOL. Therefore, we exam the current Korean orthography examples of Slovene words and suggest amendments based on the origin pronunciation. In order to avoid further confusion and to provide the foundation of Korean Orthography of Slovene words, we firstly demonstrated a comparison table of Slovene alphabet (abeceda) and Korean alphabet (Hangeul) supported with examples of Slovene words, and then suggested detailed guidelines on how to write Slovene words in Hangeul.
\end{abstract}

Keywords: Korean orthography; Korean; Slovene; loanwords; foreignwords; spelling problems with Slovene words in Hangeul

\section{Povzetek}

Članek najprej predstavi Korejski zapis prevzetih besed and zgodovino prevzemanja. S stopnjevanjem kulturnih in ekonomskih izmenjav med Korejo in Slovenijo se je povečala tudi potreba po pravopisnih pravilih, ki bi besede slovenskega izvora primerno uvrstila v korejski zapis. Srbohrvaščina sicer ni uradni jezik v Sloveniji, vendar so trenutno korejske besede, ki so izvorno slovenske, zapisane po pravopisnih pravilih, ki so postavljena za izvorno srbohrvaške besede. $V$ raziskavi torej najprej analiziramo primere zapisa slovenskih besed $v$ korejščini in predlagamo spremembe, $s$ katerimi bi korejski zapis bolj približali izgovarjavi izvorne besede. $Z$ namenom, da bi se izognili nadaljni zmedi ter da bi podali osnovo pravopisnim pravilom za slovenske besede v korejščini, smo najprej primerjali slovensko abecedo in korejski zapis hangul in dodali primere, zatem pa predlagali natančna pravila za zapis slovenskih besed v korejščini.

Ključne besede: korejski zapis; korejščina; slovenščina; prevzete besede; tujke; problemi pri zapisovanju slovenskih besed $v$ hangulu 


\section{Introduction}

Recently, interest for Slovenia in Korea is increasing as there are more cultural and economic exchanges between the two countries. Slovenia has been exposed to Koreans by mass media more and more. There were documentaries and traveling TV shows introducing beautiful, peaceful and green Slovenia to Koreans. Moreover, Slovenia became production locations for Korean television series ${ }^{1}$ and for a real variety show ${ }^{2}$. In addition, SNG Drama Ljubljana (Slovene National Theatre) performed plays in Korea, The Crazy Locomotive (폭주 기관차) in 2015 and Faust (파우스트) in 2016 as they were invited to the Seoul Performing Arts Festival for two consecutive years. Conversely, Korean animated children's television series Robocar Poli (로보카 폴리) has been airing for more than a year in Slovenia. In the field of publication, several books on Slovenia and Ljubljana have been published recently in Korea. ${ }^{3}$ Interexchange is also very active in the filed of sports, where during the PyeongChang 2018 Winter Olympic Games many Slovene athletes played well and gained the attention of Koreans. Mitja Gasparini ${ }^{4}$, a Slovene volleyball player for example, is very popular in the VLeague (South Korean club volleyball competition). Getting more and more familiar to Koreans, Slovenia became a fascinating tourist destination, with the number of tourists from Korea increasing every year.

Korean Studies of the Department of Asian Studies at the Faculty of Art, University of Ljubljana, have been receiving questiones on how to pronounce and write Slovene words in Korean by institutions and public organizations as well as individuals. This suggests that Slovene words are spoken and written among Koreans for their communication not only among people of certain backgrounds but in general public. Being aware of the need, the Orthography Commission ${ }^{5}$ The Slovenian Academy of Sciences and $\mathrm{Art}^{6}$ in cooperation with the Department of Asian Studies at the Faculty of Arts, University of Ljubljana, proposed the guidelines on how to write and pronounce Korean names in Slovene based on Korean Romanization. ${ }^{7}$ The guidelines were published in February 2018 on the occasion of PyeongChang 2018 Winter Olympic

\footnotetext{
${ }^{1}$ Filming of Dear My Friends (디어 마이 프렌즈) in 2016, which had more than 5\% audience ratings at average and Black Knight: The Man Who Guards Me (흑기사) in 2017, which had more than $10 \%$ audience ratings at average.

${ }^{2}$ Filming of Hiring a village for a short time (잠시만 빌리지) was in 2018. A real variety show is a combination of reality and variety program. This real variety show showed how a married couple with their baby lived in Slovenia for 2 weeks. The married couple were Korean singers, and they sang and played guitar in Vlado Kreslin's concert.

${ }^{3}$ Kang Byoung Yoong. (2015). Ljubljana, a city that resembles my wife (류블랴나, 아내를 닮은 도시). Paju: Nanda. Kim Yideum. (2016). Dear Slovenia (디어 슬로베니애). Goyang: Logopolis.

${ }^{4}$ Mitja Gasparini belongs to Incheon Korean Air Jumbos.

${ }^{5}$ Pravopisna komisija, 맞춤법 위원회

${ }^{6}$ The Slovenska Academija Znanosti in Umetnosti, , 슬로베니아 학술원

${ }^{7}$ Cf. Provapisna Komisija Pri SAZU in ZRC SAZU http://pravopisna-komisija.sazu.si/Priporočila.aspx
} 
Games. What is also of great importance and still needs to be done is to set Korean orthography guidelines for words of Slovene origin.

Korea and Slovenia carry a common view that their languages should preserve some distance towards the flood of foreign words coming mostly from English, as young generations consume foreign words without repulsion. Some groups of people fear that with such tendencies language destruction is unavoidable. In this regard it is meaningful that Korean orthography of loanwords gets attention in Sloveniad, and that Slovenes get familiar with principles on how to spell foreign words in Korean Hangeul (한글).

Korea published 'Korean Orthography of Loanwords' ${ }^{8}$ under the 'Framework Act on the National Language (국어기본법)' The definition of a loanword, which is most widely accepted in Korea, is a word that has assimilated into Korean and used as a Korean word. As of October 31 in 2018, there were 59,210 words included in the Korean loanword orthography examples on the webpage of National Institute of Korean Language, and 47 words out of them were from Slovene. These loanword examples are mostly proper nouns such as personal and place names, and this is the same for Slovene words. Although the guidelines are called Korean orthography of loanwords, in reality, there are rather few real loanwords, which were assimilated into Korean and used as Korean words, such as 셔츠 'shirts', 아파트 'apartments', 라디오 'radio', 미팅 'meeting' etc. Lee Sang-gyu (2011, pp. 140-141) says that it is appropriate to call the current Korean orthography of loanwords as Korean orthography of foreign words in a strict sense as these guidelines are used to spell not only loanwords but also foreign words. With the development of technology and internet, the whole world became a global village, and proper nouns such as place names and personal names are nowadays exposed in real time and sometimes unexpectedly. Such words often enter written or spoken language for a single use, however, after several times they may become assimilated into Korean. It is not possible to determine whether foreign words with Korean spelling are loanwords or not as it takes time for a foreign word to get assimilated into Korean and become a loanword. This paper addresses Slovene words rather than Slovene loanwords, but the expressions Korean Orthography of Loanwords (KOL hereafter) and the Publication of

\footnotetext{
${ }^{8}$ This is our English translation of 외래어 표기법 because there is no official English name. These guidelines will be mentioned in this paper many time with the abbreviation KOL.

${ }^{9}$ The purpose of 'Framework Act on the National Language (국어기본법)' is to improve the quality of cultural life of the people and to contribute to the development of national culture by promoting creative thinking power of the people by promoting the use of the Korean language and setting the basis for development and conservation of Korean language, and this act covers how to promote the usage of Korean language, how to improve the Korean language ability of the people and how to popularize. This act is the foundation of 'Korean Orthography (한글 맞춤법)', 'Korean Standard Language Regulation (표준어 규정)', 'Korean Standard Pronunciation Rules (표준 발음법)', 'Korean Orthography of Loanwords (외래어 표기법)' and 'Revised Romanization of Korean (국어의 로마자 표기법)'.
} 
Loanword Orthography Examples will be maintained because they are official names at present.

For now, there are no guidelines on how to spell Slovene words in Hangeul. There exist guidelines for Serbo-Croatian, the official language of former Yugoslavia, which included areas of the present day Serbia, Croatia, Bosnia and Herzegovina, Montenegro, North Macedonia, Kosovo, and Slovenia. Close examination of the Korean orthography and 47 Slovene words listed in the Loanword Orthography Examples showed that the words were spelled based on the rules for Serbo-Croatian. In principle, the orthography of personal names and place names from foreign origin should follow the provisions of Chapter 1, Chapter 2 and Chapter 3 of the KOL, however, personal names and place names from the languages which are not listed in $\mathrm{KOL}$ should be spelled based on their original pronunciation. In spite of these guidelines, in case of new foreign words from Slovene, people tend to follow the KOL for Serbo-Croatian probably because of the historical background and because Serbo-Croatian and Slovene belong to the group of South Slavic languages. However, Serbo-Croatian is not the official language of the Republic of Slovenia ${ }^{10}$, and is different from Slovene, so KOL for Serbo-Croatian should not be accepted as appropriate for Slovene words. For example, Peter Prevc is spelled as 페테르 브레브츠/peter prevt// in the loanword orthography examples, but it is recommended to be spelled as 페테르 브레우쯔/peter preuts/because "v" in "Prevc" is pronounced as $/ \mathrm{u} /$ before consonants or in word final positions in Slovene. Sounds written as $\mathrm{c} / \mathrm{ts} /$ and $\mathrm{c} / \mathrm{t} /$ / in Slovene are different phonemic sounds. Another example is the case of Mitja Gasparini. His name in Korean is written as 미차 가스파리니 /miča gasparini/, and people call him 가스파 /gaspa/ although his name is 미탸 /mitja/. Besides, when we look into how Koreans use Slovene words for their communication, we can see that Koreans spell Bohinj in two ways: 보힌/bohin/ pronouncing nj as / $\mathrm{n} /$ and 보히니/bohini/ pronouncing nj as [nI] on the internet and say the same in their conversation although 보힌/bohin/ is closer to the native pronunciation. All these examples lead to confusion. As there has been no discussion on this issue either in Korea or in Slovenia until now, this study would deal with the topic by providing information on Slovene alphabet and its pronunciation to avoid further confusion and to provide the foundation for detailed guidelines on Slovene loanwords in Korean.

In this study, we first introduce Korean Orthography of Loanwords (KOL) and its history in Section 2.1 and 2.2. We further describe KOL for Serbo-Croatian in Section 2.3, and current examples of Slovene words spelled in Korean in Section 2.4. Slovene alphabet and its pronunciation are described in Section 3.1 and 3.2. Our suggestion of detailed guidelines for KOL for Slovene is presented in Section 3.3, and propose amendments of some Slovene words spelled in Korean based on today's Slovene

\footnotetext{
${ }^{10}$ Lee Sang-gyu (이상규, 2011, p. 163) points out this matter. See, "Fundamental Law of languages" based on "foreign words notation" Analysis (국어 기본법에 근거한 외래어 표기법의 문제). The Korean Language and Literature (국어국문학회).C
} 
alphabet and pronunciation in Section 3.4. In the Conclusion, we present a comparison table of the Slovene alphabet (abeceda) and Hangeul, and the Korean orthography examples of typical Slovene names, surnames and major city names as appendices.

\section{Korean Orthography of Loanwords}

\subsection{Korean Orthography of Loanwords and its history}

In South Korea, spellings of words from other languages in Hangeul are guided by the Korean Orthography of Loanwords, which was introduced on 7 January 1986 by the former Ministry of Culture and Education (문교부) of Republic of Korea. Now the National Institute of Korean Language (국립국어원) under the Ministry of Culture, Sports and Tourism (문화체육관광부) is responsible for these guidelines, modifications and supplementation.

Since September in 1991, The Joint Committee of the Government and Press on Loanwords Review (정부•언론 외래어 심의 공동위원회) ${ }^{11}$ under the National Institute of Korean Language (국립국어원) has made several decisions and reviews on how to spell foreign words and loanwords in Korean, which is the base for the National Language Deliberation Council (국어심의회) to announce loanwords after deliberation. ${ }^{12}$

In the $\mathrm{KOL}$, there are basic principles and detailed guidelines for spelling words from English, German, French, Spanish, Italian, Japanese, Chinese, Polish, Czech, SerboCroatian, Romanian, Hungarian, Swedish, Norwegian, Danish, Malay-Indonesian, Thai, Vietnamese, Portuguese, Dutch, and Russian. There is also a comparison table of alphabets of languages, and corresponding Hangeul. ${ }^{13}$ Among 21 languages, four languages, i.e. Polish, Czech, Serbo-Croatian, and Russian, belong to Slavic languages. The KOL is trying to reflect the original local pronunciation (원지음) of each language as much as possible.

The orthography used in South and North Korea from around 1930s was based on the Draft for Standardized Korean Orthography (한글맞춤법 통일안, 1933) established by the Korean Language Society (조선어 학회, 현 한글 학회). A part of it is dedicated to the orthography of loanwords. In this part of the guidelines it is specified that the orthography of loanwords should be based on phonetic realization of the word origin, and that it is not allowed to use other alphabets or signs than Korean consonants and

\footnotetext{
${ }^{11}$ As to the Joint Committee of the Government and Press on Loanwords Review, refer to the webpage of National Institute of Korean Language. https://www.korean.go.kr/popup/committee.do ${ }^{12}$ As to the deliberation on orthography of loanword, refer to article 4.4. Retrived from National Law Information center. http://www.law.go.kr/법령/국어심의회규정/(01977,19641110)

${ }^{13}$ But as for English, German and French, IPA and Hangeul comparison table is specified with detailed guidelines instead of individual language's alphabet and Hangeul.
} 
vowels. After several revisions, the current KOL was set up in 1986 in South Korea, and there have been some amendments until now. The brief history is in Table 1 below. ${ }^{14}$

Tabela 1: History of Korean orthography of loanwords

Institution
Korean Language Society
(조선어 학회)

Korean Language Society (조선어 학회)

Former Ministry of Culture and Education (문교부)

Former Ministry of Culture and Education (문교부)

Former Ministry of Culture and Education (문교부)
Year Name of Transcription Guidelines

1933 Draft for Standardized Korean Orthography that covers Loanwords transcription (한글 맞춤법 통일안)

1940 Draft for Standardized Loanwords Transcription Guidelines (외래어 표기법 통일안)

1948 Guidelines for transcribing adopted words from abroad $^{15}$

(들온말 적는 법)

1958 Guidelines for transcribing the Roman alphabet in Korean (로마자의 한글화 표기법)

1986 KOL, Notification No. 85-11 of the Ministry of Culture and Education (외래어 표기법, 문교부 고시 제 8511 호) $)^{16}$

The National Institute of the 1992 Supplements for languages in the East European bloc, Korean Language (국립국어연구원)
Notification No. 1992-31 of the Ministry of Culture (동구권 언어의 자모와 한글 대조표 제시, 문화부 고시 제 1992-31 호) ${ }^{17}$

\footnotetext{
${ }^{14}$ History of Orthography Guidelines of Loanwords, refer to Lee, Sang-gyu (2011, p. 149); Lee, Gyeong-suk (2016, pp. 111-136); Lim, Hong-bin (1996, pp. 28-29) and sources retrived from webpage of National Institute of Korean Language

https://www.korean.go.kr/niklintro2/20years05 01 02.jsp.

${ }^{15}$ Among the guidelines mentioned in Table 1, the 'Guidelines for transcribing adopted words from abroad (들온말 적는 법)' announced in 1948 were different from others in the sense that they allowed to spell foreign words based on their phonetic values. In order to renresent foreign sounds which do not exist in Korean phonetic system, ancient Hangeul letters, i.e. $\Delta$, 붕, 픙, and 22 , were reintroduced for specific foreign words. However, these guidelines were not maintained for a long time and their use was omitted in 1958, based on the opinion that the complexity impeded wide dissemination of these guidelines. See National Library of Korea

http://www.nl.go.kr/nl/search/search.jsp?all=on\&topF1=title author\&kwd=들온말\%20 적는\%20 법.

${ }^{16}$ These guidelines included detailed rules for English, German, French, Spanish, Italian, Japanese and Chinese.

${ }^{17}$ The comparison tables of corresponding alphabet and Hangeul as well as detailed guidelines for Polish, Czech, Hungarian, Serbo-Croatian, and Romanian supplemented and announced.
} 
Institution

Year Name of Transcription Guidelines

The National Institute of the 1995 Supplements for languages in the North European

Korean Language

(국립국어연구원)

block, Notification No. 1995-8 of the Ministry of Culture (북구권 언어의 자모와 한글 대조표 제시, 문화

체육부 고시 제 1995-8 호) ${ }^{18}$

The National Institute of the 2004 Supplements for languages in Southeast Asia,

Korean Language

(국립국어원) $^{19}$

Notification No. 2004-11 of the Ministry of Culture and

Tourism (동남아시아 3 개 언어 자모와 한글 대조표

제시, 문화관광부 고시 제 2004-11 호) ${ }^{20}$

The National Institute of the 2005 Supplements for Portuguese, Dutch and Russian,

Korean Language

Notification No. 2005-32 of the Ministry of Culture and

(국립국어원)

Tourism (포르투갈어, 네덜란드어, 러시아어 자모와

한글 대조표 제시, 문화관광부 고시 제 2005-32 호)

The National Institute of the 2014 Partial amendments of Korean orthography of Korean Language

(국립국어원)

loanwords 1986, Notification No. 2014-43 of the

Ministry of Culture, Sports and Tourism (외래어 표기법 일부 개정안, 문화체육관광부 고시 제 2014-43 호)

National Institute of Korean 2017 Partial amendments of Korean orthography of Language (국립국어원) ${ }^{21}$

loanwords 1986, Notification No. 2017-14 of the

Ministry of Culture, Sports and Tourism (외래어 표기법 일부 개정안 문화체육관광부 고시 제 2017-14 호)

As can be seen in Table 1, the guidelines currently used are the KOL announced with Notification No. 85-11 of the Ministry of Culture and Education in 1986. After the announcement, the guidelines have been updated with supplements in additional languages. Besides, in case of mistakes, missing information, or inconsistency among language rules, amendments have been made to avoid confusion and to present correct language guidelines. We expect that such supplements for additional languages and partial amendments will be issued in the future as well.

Before the enactment of these rules, the Textbook Compilation Bureau under the Former Ministry of Culture and Education decided how to spell loanword and published

\footnotetext{
${ }^{18}$ A comparison table of corresponding alphabet and Hangeul as well as detailed guidelines for Swedish, Norwegian and Danish supplemented and announced.

${ }^{19}$ Only Korean name of the institute changed from 국립국어연구원 (The National Institute of the Korean Language) to 국립국어원 (The National Institute of the Korean Language) in 2004.

${ }^{20} \mathrm{~A}$ comparison table of corresponding alphabet and Hangeul as well as detailed guidelines for Malay-Indonesian, Thai and Vietnamese supplemented and announced.

${ }^{21}$ The English name of the institute changed from The National Institute of the Korean Language to National Institute of Korean Language in 2015.
} 
Textbook Editing Materials (편수자료), proposing the related examples for each subject and those textbook editing materials were published by $1987 .{ }^{22}$

With the enactment of KOL, National Institute of Korean Language published Loanwords Orthography Examples with explanations in order to disseminate the guidelines consistently: ${ }^{23}$

- 1988 Publication of Loanwords Orthography Examples (general term, place names and personal names ${ }^{24}$ ). ${ }^{25}$ 외래어 표기 용례집 (일반 용어, 지명, 인명)

- 1993 Publication of Loanwords Orthography Examples: place names and personal names in the East European bloc 외래어 표기 용례집 (동구권 인명·지명)

- 1995 Publication of Loanwords Orthography Examples: place names and personal names in the North European bloc 외래어 표기 용례집 (북구권 인명·지명)

- 2002 Publication of Loanwords Orthography Examples: place names 외래어 표기 용례집 (지명) Publication of Loanwords Orthography Examples: personal names 외래어 표기 용례집 (인명)

- 2004 Publication of Loanwords Orthography Examples for 3 languages in Southeast Asia: Malay-Indonesian, Thai and Vietnamese 동남아 3 개 언어 외래어 표기 용례집 (말레이인도네시아어, 타이어, 베트남어)

- 2005 Publication of Loanwords Orthography Examples: Portuguese, Dutch and Russian 외래어 표기 용례집 (포르투갈어, 네덜란드어, 러시아어)

\subsection{The composition and basic principles of KOL}

KOL consists of four chapters: Chapter 1 "The basic principles of orthography", Chapter 2 "A comparison table of orthography", Chapter 3 "The detailed guidelines", and Chapter 4 "The principles of spelling personal names and place names". In Chapter 1, there are five clauses as shown below ${ }^{26}$ :

Clause 1. Loanwords should be written with the 24 Korean letters currently in use.

Clause 2. One phoneme of a loanword should principally be written with one Korean letter (grapheme).

\footnotetext{
${ }^{22}$ Lee, Gyeong-suk (2016, p. 109).

${ }^{23} \mathrm{Cf}$. https://www.korean.go.kr/niklintro2/20years05 $0102 . j \mathrm{sp}$

${ }^{24}$ Authors use personal names and place names in this paper instead of proper noun as these are stipulated in the guidelines.

${ }^{25}$ It was published by the Research Institute of the Korean Language 국어연구소 which is former National Institute of Korean language.

${ }^{26}$ The guidelines of KOL was translated by authors.
} 
Clause 3. A syllable coda, called batchim 받침 ${ }^{27}$, should be written written using 'ᄀ, ᄂ, ㅁ, ᄅ, ㅂ, 人, O'.

Clause 4. No tense consonants should be used for spelling plosives. ${ }^{28}$

Clause 5. For loanwords in use, which need corrections, the existing common usage should be respected. The scope and examples should be decided separately.

In Chapter 2 of the KOL, comparison tables of alphabet in 18 languages including IPA transcription of Hangeul are presented. In Chapter 3, detailed guidelines are given for 21 separate languages and they deal with differences between Korean and target languages, specifying that we should write in accordance with the comparison table, following distinct features of each language. In Chapter 4, the spellings of personal names and place names are proposed in Clause 1, the spellings of words that originate in Asian languages are proposed in Clause 2, and the spellings of names of seas, islands, rivers, mountains, etc. are proposed in detail in Clause 3.

These principles and clauses show that KOL is under the guidelines of Korean Orthography and requires the spellings of loanwords according to Korean phonological system. There is an opinion that the comparison table of each language is of no use at all because the IPA and Hangeul comparison table could be used for all languages like English, German, and French work (Lee, 2016). But it is important to make the comparison table and detailed guidelines for each foreign language, so that all users of KOL conveniently check and use them because not all users have knowledge about the IPA symbols and not all languages indicate their pronunciation with IPA symbols in their dictionary, e.g. Slovene, Italian, and Spanish, etc. In addition, as KOL proposed to spell proper nouns according to the original local pronunciation of each language, it is more appropriate to make the comparison table for each language not to make it a useless document. Other studies (Cho \& Park, 2015; Choi, 2014; Jang, 2002; Park, 1997) have shown that in case guidelines do not reflect the original local pronunciation fully, this causes confusion and eventually stops experts of each language as well as general public to use them adequately.

\footnotetext{
${ }^{27}$ Hanguel is a syllabic alphabet and has 5 different types of syllable structures, i.e. V (e.g. 오 'five'), CV (e.g. 소 'cow'), VC (e.g. 알 'egg'), CVC (e.g. 강 'river'), and CVCC (e.g. 닭 'chicken'). In the syllable structures of VC, CVC, and CVCC, the last consonant or the cluster of two consonants are called batchim, and are written at the bottom of the syllabic structure. According to the Korean Standard Pronunciation Rules, only 7 consont sound values are possible in the position of batchim. Those are ᄀ, ᄂ, ᄅ, ㅁ, ㅂ, 人, and 0 .

${ }^{28}$ Korean has plain, aspirated and tense sounds for both plosives and affricates, and plain and tense sounds for fricatives. According to this clause, tense sounds, i.e. 7 , $\llbracket$ and $\forall$ are not allowed to use to transcribe/spell loanwords. Additionally, as to loanwards derived from English, German, French and Italian, it is not allowed to use tense sounds for affricates and fricatives, $i$.e. allowed to use. For example, Paris 파리 not * 빠리, service 서비스 not * 써비스, Mozart 모차르트 not $*$ 모짜르트.
} 
There are several controversial issues in $\mathrm{KOL}$. To begin with, there is no clear distinction between foreign words and loanwords. Secondly, it is not clear whether proper nouns are the objects of KOL or not. Thirdly, there are conflicting opinions on whether transcription should be based on the pronunciation of a source language or Korean phonological system. Fourthly, there are many mistakes in loanwords' orthography examples, or else KOL is not followed well. Finally, different principles have been applied for loanwords of different origin. Words from English, German and French, for example, are spelled based on the IPA and Hangeul comparison table while words from the other languages are spelled based on their own alphabet and Hangeul comparison tables.

Therefore, we first propose to change the name of guidelines from 'Korean Orthography of Loanwords' to 'Korean Orthography of Foreign Words'. As mentioned above, it is almost impossible to know whether words from foreign languages could be assimilated into Korean or not in this early stage of spelling foreign words in Korean. If the name of guidelines is changed, the scope of KOl would be expanded and this could be a solution for arguments on whether proper nouns are scope of KOL or not. As for the principles of spelling loanwords, it should be acknowledged that a user of KOL is most likely Korean, and that a user can use it freely and conveniently only when they feel comfortable with the principles. Besides, the principles are ment only for spelling foreign words ${ }^{29}$, and that they should be based on Korean phonological system while trying to reflect the pronunciation of a source language. Additionally, it seems that more government's efforts are needed to call attention from academic circles, publishing houses, mass media, and general public to obtain critical thinking and suggestions on the existing guidelines. ${ }^{30}$ Lastly, we suggest that the guidelines including the IPA and Hangeul comparison tables for spellings of German and French words do not sufficiently represent pronunciations of words in a source language. Therefore, it would be appropriate to make their own alphabet and Hangeul comparison tables with detailed guidelines separately like it was done for other languages.

\subsection{KOL for Serbo-Croatian}

The guidelines with 72 examples for Serbo-Croatian were added to KOL in 1992, though in those times the Socialist Federal Republic of Yugoslavia has already collapsed. Both Slovene and Serbo-Croatian belong to the group of South Slavic languages. Officially, Slovene language has 25 letters (20 consonant and 5 vowel letters) and Serbo-Croatian 30 letters ( 25 consonant and 5 vowel letters), however, these two languages have some different pronunciation rules. As of January 2019, there were 269 loanword

\footnotetext{
${ }^{29}$ Yu Kyung-Sook. (2002, p. 17) says that these guidelines are not to spell the sounds of foreign languages to teach or learn the pronunciation of foreign languages but to present the orthography of foreign words within our phonological system for the Korean's consistency in use.

${ }^{30}$ Mistakes in Korean orthography examples of Slovene words are detected. See. footnote, 32-35.
} 
orthography examples belonging to the section of Serbo-Croatian, with mainly proper nouns originating from languages in Slovenia, Croatia, Serbia, Montenegro, Kosovo, and even Bulgaria. Below are the detailed KOL guidelines for Serbo-Croatian. A comparision table of Serbo-Croatioan alphabet and Hangeul is in Table 2 below.

Table 2 : Comparison Table of Serbo-Croatian alphabet and Hangeul with examples ${ }^{31}$

\begin{tabular}{|c|c|c|c|}
\hline & \multicolumn{2}{|l|}{ Hangeul } & \multirow[b]{2}{*}{ Orthography examples } \\
\hline & before V & $\begin{array}{l}\text { before } \mathrm{C} \text {, } \\
\text { at the final }\end{array}$ & \\
\hline \multicolumn{4}{|c|}{ Consonants } \\
\hline$b$ & 日 & 브 & $\begin{array}{l}\text { bog 보그, drobnjak 드로브냐크, } \\
\text { pogreb 포그레브 }\end{array}$ \\
\hline C & え & 츠 & cigara 치가라, novac 노바츠 \\
\hline č & え & 치 & čelik 첼리크, točka 토츠카, kolač 콜라치 \\
\hline$c, t \mathrm{tj}$ & え & 치 & nać 나치, sestrić 세스트리치 \\
\hline d & $\sqsubset$ & 드 & desno 데스노, drvo 드르보, medved 메드베드 \\
\hline $\mathrm{dž}$ & ス & 지 & džep 제프, narudžba 나루지바 \\
\hline đ, dj & ス & 지 & Đurađ 주라지 \\
\hline$f$ & 표 & 프 & fasada 파사다, kifla 키플라, šaraf 샤라프 \\
\hline g & $\neg$ & 그 & gost 고스트, dugme 두그메, krug 크루그 \\
\hline $\mathrm{h}$ & $\overline{\mathrm{O}}$ & $\underline{\overline{\mathrm{O}}}$ & hitan 히탄, šah 샤흐 \\
\hline $\mathrm{k}$ & $\exists$ & ᄀ, ᄏコ & korist 코리스트, krug 크루그, jastuk 야스투크 \\
\hline I & ᄅ, ᄅᄅ & ᄅ & levo 레보, balkon 발콘, šal 샬 \\
\hline lj & ㄹ,리 & ᄅ & ljeto 레토, pasulj 파술 \\
\hline $\mathrm{m}$ & $\square$ & ㅁ, 므 & malo 말로, mnogo 므노고, osam 오삼 \\
\hline $\mathrm{n}$ & 니+ & ᄂ & nos 노스, banka 반카, loman 노만 \\
\hline nj & ᄂ & ᄂ & Njegoš 네고시, svibanj 스비반 \\
\hline$p$ & 표 & ㅂ, 프 & peta 페타, opština 옵슈티나, lep 레프 \\
\hline r & ᄅ & 르 & riba 리바, torba 토르바, mir 미르 \\
\hline s & 人 & 스 & sedam 세담, posle 포슬레, glas 글라스 \\
\hline š & 시 & 슈, 시 & šal 샬, vlasništvo 블라스니슈트보, broš 브로시 \\
\hline $\mathrm{t}$ & $E$ & EE & telo 텔로, ostrvo 오스트르보, put 푸트 \\
\hline v & ᄇ & 브 & vatra 바트라, olovka 올로브카, proliv 프롤리브 \\
\hline $\mathrm{z}$ & ス & 즈 & zavoj 자보이, pozno 포즈노, obraz 오브라즈 \\
\hline$\underline{\text { ž }}$ & 즈 & 주 & žena 제나, izložba 이즐로주바, muž 무주 \\
\hline
\end{tabular}

${ }^{31}$ National Institute of Korean Language. Retrived from https://www.korean.go.kr/front/page/pageView.do?page id=P000112\&mn id=97 


\section{Semivowel}

\begin{tabular}{lll}
\hline $\mathrm{j}$ & 이※ & pojas 포야스, zavoj 자보이, odjelo 오델로 \\
\hline \multicolumn{2}{l}{ Vowel } & \\
\hline $\mathrm{a}$ & 아 & bakar 바카르 \\
$\mathrm{e}$ & 에 & cev 체브 \\
$\mathrm{i}$ & 이 & $\operatorname{dim}$ 딤 \\
0 & 오 & molim 몰림 \\
$\mathrm{u}$ & 우 & zubar 주바르 \\
\hline
\end{tabular}

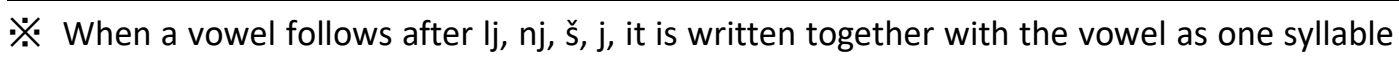
‘리, 니, 시, 이’.

\subsubsection{Detailed guidelines ${ }^{32}$}

There are 5 clauses that payed our attention.

Clause 1. When $k, p$ are a syllable coda position and appear before voiced consonants, they should get the epenthetic vowel $O / \mathrm{m} /$, but when these are placed before voiceless consonants, they should be transcribed as a syllable final consonant 받침.

jastuk 야스투크, opština 옵슈티나

Clause 2. When $/$ and $l j$ in the middle of a word appear before vowels, they should be transcribed as ᄅᄅ/-II-/, ᄅ己ᄅ/-Ili/.

kula 쿨라, Ljubljana 류블랴나

Clause 3. When initial consonant letter $m$ is placed before $l, r$, or $n$, or else $m$ appears in a middle position before $r$, it should be transcribed together with the following epenthetic vowel $0 / \mathrm{m} /$.

mlad 믈라드, mnogo 므노고, smrt 스므르트

Clause 4. When š stands before a consonant, it should be transcribed as 슈/Jju/, while $\check{s}$ in a final position becomes 시/Ji/.

šljvovica 슐리보비차, Niš 니시

Clause 5. When consonants combine with je, they should get transcribed as 에/e/ and not 예/je/. Exception is a consonant letter $s$, which transcribes as 셰//je/.

bjedro 베드로, sjedlo 셰들로

\footnotetext{
32 Detailed guidelines have been translated by authors.
} 
With the Comparison Table of alphabet transcription and the above guidelines, the original local pronunciation is reflected as close as possible with Hangeul and Korean orthography.

\subsection{Current status of loanword orthography samples from Slovene}

Anyone interested in how to spell loanwords in Hangeul can find loanword orthography examples on the website of the National Institute of Korean Language by searching the following keywords: Hangeul orthography (한글표기), original language orthography (원어표기), name of country (국명), etc.

With the keyword 슬로베니아 (Slovenia) searched for on Oct 31, 2018, the list on the web showed 47 Slovene words in Korean, all of them being proper nouns.

Table 3: Loanword orthography examples of Slovene words from the website of the National Institute of Korean Language ${ }^{33}$

\begin{tabular}{lll}
\hline No. & Slovene word & Loanword orthography in Korean \\
\hline 1 & Ljubljana & 류블랴나 \\
2 & Maribor & 마리보르 \\
3 & Slovenia $^{34}$ & 슬로베니아 \\
4 & Trieste $^{35}$ & 트리에스테 \\
5 & Postojna & 포스토이나 \\
6 & Drnovšek, Janez & 드르노브셰크, 야네즈 \\
7 & Janez Premoze & 야네즈 프레모제 \\
8 & Kučan, Milan & 쿠찬, 밀란 \\
9 & Janša, Janez & 얀샤, 야네즈 \\
10 & Danilo Türk & 튀르크, 다닐로 \\
11 & Čeplak, Jolanda & 체플라크, 욜란다 \\
12 & Zolnir, Urska (Urška Žolnir) & 졸니르, 우르슈카 \\
13 & Cop, Iztok (Iztok Čop) & 초프, 이즈토크 \\
14 & Spik, Luka (Luka Špik) & 슈피크, 루카 \\
15 & Zbogar, Vasilij (Vasilij Žbogar) & 주보가르, 바실리 \\
16 & Tokic, Bojan (Bojan Tokić) & 토키치, 보얀 \\
17 & Kozmus, Primož & 코즈무스, 프리모즈 \\
18 & Polavder, Lucija & 폴라브데르, 루치야 \\
\hline
\end{tabular}

${ }^{33}$ The table is mentioned in this paper without any correction. Retrived October 31, 2018 from https://www.korean.go.kr/front/foreignSpell/foreignSpellList.do;front=D60B9400A217F31411BB2 782218AC7AF?mn_id=96\&pagelndex=1 accessed Oct. 31, 2018.

${ }^{34}$ Slovenia is the English spelling of Slovenija. The official name is Republika Slovenija.

${ }^{35}$ Trieste is a city in a Italian-Slovene bilingual area of today's Italy, Slovene name for it is Trst.

${ }^{36}$ Original spelling of this surname Premoze is Premože. 


\begin{tabular}{lll}
\hline No. & Slovene word & Loanword orthography in Korean \\
\hline 19 & Debevec, Rajmond & 데베베츠, 라이몬트 \\
20 & Isakovic, Sara (Sara Isakovič) & 이사코비치, 사라 \\
21 & Brežice & 브레지체 \\
22 & Celje & 첼레 \\
23 & Cerknica & 체르크니차 \\
24 & Črnomelj & 츠르노멜 \\
25 & Drava 강 & 드라바강 \\
26 & Idrija & 이드리야 \\
27 & Istria 반도 & 이스트리아반도 \\
28 & Julijske 산맥 & 율리이스카산맥 \\
29 & Kočevje & 코체베 \\
30 & Kranj & 크란 \\
31 & Krško & 크르슈코 \\
32 & Kupa 강37 & 쿠파강 \\
33 & Mura 강 & 무라강 \\
34 & Murska Sobota & 무르스카소보타 \\
35 & Novo Mesto & 노보메스토 \\
36 & Piran & 피란 \\
37 & Katarina Srebotnik & 스레보트니크, 카타리나 \\
38 & Ptuj & 프투이 \\
39 & Sava 강 & 사바강 \\
40 & Škofja Loka & 슈코퍄로카 \\
41 & Tolmin & 톨민 \\
42 & Žižek, Slavoj & 지제크, 슬라보이 \\
43 & Potrč, Marjetica & 포트르치, 마레티차 \\
44 & Janković, Zoran & 얀코비치, 조란 \\
45 & Pahor, Borut & 파호르, 보루트 \\
46 & Bratušek, Alenka & 브라투셰크, 알렌카 \\
47 & Prevc, Peter & 프레브츠, 페테르 \\
\hline & &
\end{tabular}

When we exam loanwords orthography examples of Slovene words in Table 3, we find discrepancies between the original Slovene pronunciation and words written in Korean. Moreover, some of these words on the list are not Slovene. These shortcomings of the table come from the fact that the orthographies of these examples were made based on the guidelines for Serbo-Croatian. Therefore, it is necessary to review Slovene examples.

${ }^{37}$ Kupa river is the Croatian name. In Slovenia, this river is called Kolpa river. The river runs on the border of two nations. 


\section{Slovene alphabet and pronunciation ${ }^{38}$}

\subsection{Slovene alphabet}

The Slovene alphabet has 25 letters: A a, B b, C c, Č č, D d, E e, F f, G g, H h, I i, J j, K k, L I, M m, N n, O o, P p, R r, S s, Š š, T t, R r, V v, Z z, Ž ž. The letters q, w, x, y are sometimes found in Slovene texts but only in foreign names or borrowed expressions, e.g. New York, $x$ žarki ' $x$ rays'.

\subsection{Slovene vowel system}

Standard Slovene has seven long (stressed) vowels and six short vowels (either stressed or unstressed) written with letters $a, e, i, o$, and $u$. To denote the quantity and quality of a stressed vowel, superscript diacritics: ', ', ' are used but only in dictionaries and grammars. The Slovene vowel system is illustrated in Table 4 below.

Table 4: Slovene vowel system ${ }^{39}$

\begin{tabular}{|c|c|c|c|}
\hline \multirow[b]{3}{*}{ High } & \multicolumn{2}{|c|}{ Stressed } & \multirow{3}{*}{$\begin{array}{l}\text { Unstressed short } \\
\mathrm{i}[\mathrm{i}] \mathrm{u}[\mathrm{u}]\end{array}$} \\
\hline & Long & Short & \\
\hline & í [í:] ú [ ú:] & ì [ ì] ù [ù] & \\
\hline high mid & é [é:] ó [ó:] & & \\
\hline Mid & & á [ á] & e [ə] \\
\hline low mid & ê [ć: ] ô [ó:] & è [c̀ ] ò [ó] & $\mathrm{e}[\varepsilon] \mathrm{o}[\supset]$ \\
\hline Low & á [ à:] & à [à ] & $\mathrm{a}[\mathrm{a}]$ \\
\hline
\end{tabular}

Different from Slovene vowels, Korean vowels are pronounced without stress accent on any particular vowel. The KOL guidelines do not deal with the distinction between long and short vowels.

\subsection{Slovene consonant system}

Concerning consonants, voiceless obstruents $/ p, t, f, k, s, J /$ have their voiced counterparts which occur as individual letters in the orthography, e.g. $p-b, t-d, k-g, f-$ $v, s-z, \breve{s}-z ̌$. Voiceless obstruents $h$ and $c$ have their voiced allophonic counterparts $\gamma$ and

\footnotetext{
${ }^{38}$ This section of the paper is based on description of Slovene phonetics in Toporišič (2004), Herrity (2000), and Lečič (2012). The purpose of this article is to shed light on how to write Slovene words in Korean in Korea and the objects are mostly proper nouns. Therefore, we deal with the phonology at the word level and do not deal with suffixes, plurals, prepositions, and inflection.

${ }^{39}$ Herrity (2000, p. 7). Corresponding IPA symbols are in square brackets. ' and 'represent stressed vowels. : represents long vowels.
} 
$d z$. There are voiced sonorants / $\mathrm{m}, \mathrm{n}, \mathrm{r}, \mathrm{l}, \mathrm{j} /$. Additionally, $d$ and ž are used sequentially for the pronunciation of [dz] in a limited number of loanwords, e.g. džem 'jam'. In terms of place and manner of articulation, the Slovene consonant system is illustrated by the following table.

Table 5: Slovene consonant system ${ }^{40}$

\begin{tabular}{|c|c|c|c|c|c|c|}
\hline & labial & labio-dental & dental & alveo-palatal & palatal & velar \\
\hline voiceless stops & $\mathrm{p}$ & & $\mathrm{t}$ & & & k \\
\hline voiced stops & $b$ & & $d$ & & & g \\
\hline voiceless fricatives & & $f$ & $\mathrm{~s}$ & š []] & & $\mathrm{h}[\mathrm{x}]$ \\
\hline voiced fricatives & & $\mathrm{v}$ & z & ž [3] & & {$[\gamma] *$} \\
\hline voiceless affricates & & & $c[t s]$ & $\check{c}[t]]$ & & \\
\hline voiced affricates & & & {$[d z] *$} & $d z ̌[d z]$ & & {$[\eta] *$} \\
\hline Nasals & $\mathrm{M}$ & & $\mathrm{n}$ & & & \\
\hline Lateral & & & 1 & & & \\
\hline Roll & & & $r$ & & & \\
\hline \multirow[t]{2}{*}{ Glides } & & & & & $\mathrm{J}$ & \\
\hline & {$[\mathrm{w}] *$} & & & & & \\
\hline \multirow[t]{2}{*}{ Approximants } & {$[M] *$} & & & & & \\
\hline & {$[u$ u $] *$} & & & & & \\
\hline
\end{tabular}

\subsubsection{Obstruents and their allophones}

Obstruents appear, following phonological processes of final devoicing and regressive assimilation at the word level. In the first phonological process voiced obstruents devoice at the end of a word, e.g. grad 'castle'> [grat], rob 'edge'>[rop], laž 'lie'>[la]], Janez male personal name>[Janes]. The case of /v/ will be explained later. When two obstruents occur next to each other in a word, regressive assimilation takes place. A voiced obstruent followed by a voiceless obstruent becomes voiceless, e.g. sladko 'sweet'>[slatko], têžko 'heavy'>[tefko], Iztok male personal name>[istok], and a voiceless obstruent followed by a voiced obstruent becomes voiced, e.g. kdo 'who'> [gdo], glasba 'music'>[glazba], odločba 'rule, order'> [odlodzba].

The voiced labio-dental /v/ has allophones while it is pronounced as [v] only before vowels or before syllabic /r/, e.g. vas [vas] 'village', vôda [voda] 'water', vrt [vərt] 'garden'. In other positions,

${ }^{40}$ Peter Herrity (2000, pp. 15-16). Those appearing in square brackets with * are positional variants of phonemes and in square brackets are corresponding IPA symbols. 
(a) the phoneme / $/$ is realized as [u] when it appears at a word final after a vowel or when it appears as a syllable coda before a consonant, e.g. živ 'alive'>[iu], nov 'new'>[nou], pravzaprav 'as a matter of fact'>[prauzaprau], ôvca 'sheep'>[ouca]. The ending -ev is pronounced as [-əu], e.g. cerkev 'church'> [cerkəu].

(b) / $/$ may be realized as a voiced glide [w] at the beginning of a word, before a voiced consonant or a sonorant. For example, vzeti 'to take'>[wzeti], vlak 'train' $>$ [wlak] or when it occurs between an obstruent/sonorant and a sonorant/obstruent, e.g. odvzeti 'to take away'>[odwzeti] or at the end of a word following a sonorant, e.g. barv 'color'> [barw].

(c) / $\mathrm{V} /$ is pronounced as a voiceless bilabial approximant $[\mathrm{M}]$ at the beginning of a word, before voiceless obstruents, e.g vse 'all' $>$ [Mse], vsebina 'content' $>$ [Msebina] or when it occurs between a voiced obstruent and a voiceless obstruent, e.g. predvčerajšnjim 'the day before yesterday'>[pretmtferajfnim] ${ }^{41}$.

\subsubsection{Sonorants and their allophones}

Sonorants /m, n, l, r, j/ are all voiced. / $\mathrm{n} /$ has a nasal velar counterpart [ $\mathrm{\eta}$ ] which is realized only before phonemes $/ \mathrm{k}, \mathrm{g}, \mathrm{h} /$, as in banka 'bank'>[banka] for example.

$/ \mathrm{I} /$ is pronounced as [I] when it appears at the beginning of a word or before $/ \mathrm{j} /$, e.g. les 'wood'> [les], /polje/ 'field'> [polje], and in personal names, e.g. [paval], [vilko], [karal]. When /I/ appears between two vowels or after a consonant, it is also pronounced as [I], e.g. telefon 'telephone'>[telefon], glava 'head'>[glava], mlad 'young'>[mlat]. However, when it is at the end of a word or at the end of a syllable before a consonant, $/ \mathrm{I} /$ is normally pronounced as [u], e.g. bolha 'flea'>/bouha/, solza 'tear'>/souza/, pekel 'hell' >/pəkəu/.

$/ r /$ is a dental roll and it can be pronounced as a single consonant $[r]$ or syllabically as [ər], i.e. schwa followed by [r]. The $r$ is pronounced syllabically as [ər] when it precedes a consonant at the beginning of a word, or occurs between two consonants, e.g. smrt 'death'>[smart], vrt 'garden'>[vart], prt 'table cloth'>[pərt].

As for the glide $/ \mathrm{j}]^{42}$, when it precedes a vowel, it forms [ja], [je], [ji], [jo], [ju]. In case of consonant clusters $/ \mathrm{lj} /$ and $/ \mathrm{nj} /$, consonant sequences are pronounced as two distinct sounds at the beginning of a word when followed by a vowel or when in intervocalic position, e.g. ljubezen 'love'>[ljubezen], volja 'will'>[volja], sanje 'dream'>[sanje]. However, when they precede a consonant or occur in word final position, they are either pronounced as a simple [I] or [ $\mathrm{n}]$ in a dialect or as a single

\footnotetext{
${ }^{41}$ Herrity $(2000$, p. 18$)$ says that the $-d$-devoices before $M$.

${ }^{42}$ The $\mathrm{j}$ is considered a semivowel in Korea, and counted among vowels as there is no consonant that distinguishes a palatal approximant.
} 
palatalized consonant [l] or [n] like Kranj city name >[Kran/, konj 'horse' >[kon], knjiga 'book'>/kniga/.

\subsection{Suggestions for detailed KOL guidelines KOL of Slovene words}

On the basis of the above information on KOL, the Slovene alphabet, and pronunciation, we would like to suggest detailed guidelines for Korean orthography of Slovene words.

\section{Clause 1. Voiced obstruents}

1. When $b, d, g, z, z ̌$ appear at word final position or before a voiceless consonant, write as 프 [pm], 트 [tu], 크 [km], 스 [sm], 시 [si].

$$
\begin{aligned}
& \text { pogreb 포그레프 'funeral', } \\
& \text { grad 그라트 'castle', } \\
& \text { Janez 야네스 male name, } \\
& \text { Iztok 이스토크 male name, } \\
& \text { Matjaž 마탸시 male name, } \\
& \text { bog 보크 'god', } \\
& \text { odpad 오트파트 'dump' }
\end{aligned}
$$

2. When $b$ appears before a voiceless consonant, write as the final coda of a syllable $[b]^{43}$.

$$
\text { občina 옵치나 'municipality' }
$$

3. When $b, d, g, z$, ž appear before a voiced obstruent, write as 브 [bu], 드 [du], 그 $[\mathrm{gm}]$, 즈 [zu], 주 [zu]. ${ }^{44}$

$$
\begin{aligned}
& \text { dobre 도브레 'good', } \\
& \text { zadnji 자드니 'last' } \\
& \text { razlika, 라즐리카 'difference', } \\
& \text { možgani 모주가니 'brain' }
\end{aligned}
$$

\section{Clause 2. Voiceless consonants}

1. When $p, t, s, k, f, c, h$ appear at a word final position or before a voiceless consonant, write as 프 [pm], 트 [tm], 스 [sm], 크 [km], 프 [pm] ${ }^{45}$, 쯔 [cm], 흐 [hm].

\footnotetext{
${ }^{43}$ Cf. foot note no. 25.

${ }^{44}$ As for the pronunciation of syllables (ス, ㅉ, + palatalized vowels ya, yeo, ye, yo, yu), it is provided to pronounce as a monophthong, e.g. 자, 짜, 차, etc. by clause 5 of the rules for Korean standard pronunciation (표준 발음법 제 5 항).

${ }^{45}$ There are no labio-dental sounds in Korean, therefore we use the same $p$ sound for both $p$ and $f$, and use the same $b$ sound for both $b$ and $v$ to spell foreign words in Korean.
} 


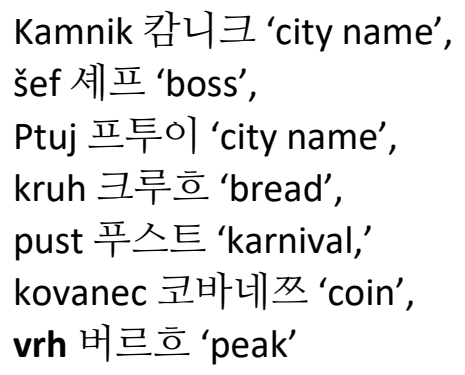

2. When $k, s$ and č precede a voiced consonant, write as 그 [gu], 즈 [zu], 주 [zu].

kdo 그도 'who',

glasba 글라즈바 'music',

odločba 오들로주바 'rule, order'

3. When $\check{c}$ appears at a word final position or before a voiceless consonant, make a syllable with 이 [i].

$$
\begin{aligned}
& \text { plačnik 플라치니크 'payer', } \\
& \text { točka 토치카 'point', } \\
& \text { moč 모치 'power' }
\end{aligned}
$$

4. When $k$ and $p$ appear before a voiceless consonant, write as the final coda of syllable $\neg[g]$, ㅂ $[\mathrm{b}] .{ }^{46}$

lekcija 렉찌야 'lesson',

oktober 옥토베르 'october',

čipka 칩카 'lace'

5. When š appears before a consonant, write as 슈 [ $\mathrm{jju}]$, when $s$ is the final consonant, transcribe as 시 [ji]. When š appears before a vowel $a, e, i, o, u$, transcribe as 샤 [Ja] , 셰 $\left[\int e\right]$, 시 [ji], 쇼 [Jo], [Ju] 슈 respectively.

številka 슈테빌카 'number',

Bekeš 베케시 family name,

šef 셰프 'boss'

\section{Clause 3. Sonorants}

1. When a non-initial / appears before a vowel, write as ᄅᄅ [-II]. Wwhen it appears at a word final position or at the end of a syllable and before a consonant, write as 우 [u]. In names, write as $2[I]$ before a consonant.

Izola 이졸라 city name,

Ljubljana 류블랴나 city name,

Pekel 페케우 cave name 'hell'

\footnotetext{
${ }^{46} \mathrm{Cf}$. foot note no. 43.
} 
bolha 보우하 'flea', Vilko 빌코 male name

2. When an initial consonant $m$ appears before $l, r, n$, write as 므 [mu]. When $m$ appears at the end of a word or before a consonant, write as the final coda of a syllable.

$$
\begin{aligned}
& \text { mlad 믈라트 'young', } \\
& \text { mnogo 므노고 'many', } \\
& \text { sejem 세옘 'fair' }
\end{aligned}
$$

3. When $n$ appear before $k, g, h$, write as a final consonant of syllable o [ $\eta]$.

banka 방카 'bank',

Angela 앙겔라 female name

4. When $r^{47}$ appears before a voiced consonant or at the end of a word, write as 르 [ru]. But when it appears initially before a voiceless consonant or between two consonants, write as 어르 [ər].

$$
\begin{aligned}
& \text { torba 토르바 'bag', } \\
& \text { mir 미르 'peace,' } \\
& \text { smrt 스머르트 'death,' } \\
& \text { vrt 버르트 'garden' }
\end{aligned}
$$

5. When $j$ appears before a consonant in the word middle position or after a vowel in syllable coda, write as 이 [i]. But when $j$ is combined with vowels $a, e, i, o, u$ transcribe as 야 [ja], 예 [je], 이 [i], 요 [jo] or 유 [ju]. When $j$ appears in a sequence with another consonant, write as one syllable. When $n j$ and $l j$ appear at word final, the $j$ is not expressed in the Korean transcription. ${ }^{48}$

$$
\begin{aligned}
& \text { jagoda 야고다 'strawberry', } \\
& \text { Velenje 벨레녜 city name, } \\
& \text { Postojna 포스토이나 city name } \\
& \text { Ptuj 프투이 city name, } \\
& \text { Kranj 크란 city name, } \\
& \text { prijatelj 프리야텔 'friend' }
\end{aligned}
$$

\footnotetext{
${ }^{47}$ There are no dental-roll sounds in Korean, therefore we use the same I sound for both I and $r$ to spell foreign words in Korean.

${ }^{48}$ Although they are a single palatalized consonant [l] or [n], there is no Hangeul to reflect relative sounds. Therefore, we should use a consonant according to the guidelines as it is required to use only Hangeul to write foreign words in Korean.
} 
Clause 4. Consonant $v$

When $v$ appears before a vowel, transcribe as $\theta[b]^{49}$. When it appears at a word final position after a vowel or when $v$ appears at the end of a syllable before a consonant, transcribe as 우 [u].

$$
\begin{aligned}
& \text { vino 비노 'wine', } \\
& \text { nov 노우 'new,' } \\
& \text { vse 우세 'all', } \\
& \text { avto 아우토 'car' }
\end{aligned}
$$

Clause 5. Consonant sequence dž

When $d$ is followed by ž, write as $ᄌ[\mathrm{~d} 3]$.

džamija 자미야 'mosque'

\subsection{Proposals for amendments of Korean orthography examples in case of Slovene words}

Based on the Korean orthography of loanwords and the suggested details for Slovene, we would like to propose amendments for some words that are alreadz included in the orthography examples from Slovene.

In accordance with suggested clauses above,

1. Clause 1.1: Janez should be written as 야네스 and not *야네즈. Iztok should be written as 이스토크 and not *이즈토크. Finally, Primož should be written as 프리모시 and not* 프리모즈.

2. Clause 3.3: Alenka should be written as 알렝카 and not *알렌카.

3. Clause 3.5: Celje should be written as 쩰례 and not*첼레. Also, Marjetica should be written as 마례티짜 and not *마레티차. ${ }^{50}$

4. Clause 4: Drnovšek should be written as 드르노우셰크 and not *드르노브셰크. Kočevje should be written as 코체우예 and not *코체베, and Polavder should be written as 폴라우데르 and not *폴라브데르.

In addition, we would like to suggest the use of the tense sound $\not>$ in order to spell the $c$ sound ${ }^{51}$. Although it is not allowed to use tense consonants for loanword

\footnotetext{
${ }^{49}$ cf. footnote no. 43.

${ }^{50}$ As to Slovene c sound, we suggest to use the tense sound $\not$ and the reason is explained.

51 In a comparison table of Serbo-Croatian and Hangeul, for both c and č sounds, a Korean sound ᄎ $[\mathrm{t}]$ is used because of the clause 4 of chapter 1 which does not allow tense sounds.
} 
orthography, there were some exceptions with Malay-Indonesian, Thai, Vietnamese, and the confirmed loanwords from Japan already. Besides, there was an argument that this orthography matter with tense sounds should be reviewed for both Eastern European languages and Russian (Lee, 2016). In Slovene, the letter c, which is pronunced as [ts], has the same quality as Hangeul ᄍ, a tense consonant. Slovene words in question do not derive from English, German, French or Italian. There is a typical and popular women's name Mojca [moitsa] (모이짜) and it sounds very strange if we pronounce it as *모이차 [moit]a], which is based on KOL for Sebro-Croatian. Therefore, considering the existence of one to one matching consonant and the original sound, it is desirable to accept the use of the tense consonant 及 [ts] for Korean orthography of Slovene words.

From the sociocultural point of view, in the 1980s when KOL was prepared and announced, it is understandable that one Korean alphabet was used for two different foreign alphabets. The first reason is that it was simple and convenient, and secondly, it was not easy for Koreans to distinguish the difference between two similar sounds: $c$ and č. However, with an increasing exposure to foreign languages there is no problem to detect the difference between the two sounds and we feel rather uncomfortable to use the same spelling for two different sounds. In addition, considering the principle of orthography, and phoneticism, it is more proper to use the tense sound 及 for $\mathrm{c}$.

Then, Lucija is 루찌야 rather than *루치야, Brežice becomes 브레지쩨 and not *브레지체, Celje is written as 쩰례 and not *첼레, Cerknica is 쩨르크니짜 and not *체르크니차 and Marjetica is 마례티짜 and not *마레티차 in order to reach the more correct pronunciation of Slovene names Korean.

\section{Conclusion and proposal}

The purpose of this paper is to introduce KOL (Korean Orthography Guidelines of Loanwords, 외래어 표기법), to review the current Korean orthography examples of Slovene words, and to shed light on the necessity to add up-to-date guidelines for Slovene to the KOL by proposing detailed guidelines with a comparison table of Slovene alphabet and Hangeul. There are several reasons for this. First, Korean orthography for Slovene words is composed based on the guidelines for Serbo-Croatian although there are differences between the two languages. Secondly, there are some Slovene words written wrongly in Korean orthography examples as well as on the internet. Such mistakes certainly lead to confusion. Finally, there is an endeavor to spell Slovene words correctly. Therefore, after introducing Korean Orthography Guidelines for Loanwords and their history, we looked in detail into the guidelines for Serbo-Croatian and Slovene alphabets, and Slovene pronunciation at a word level in order to review Korean orthography examples of Slovene words and to propose the detailed guidelines for Slovene. In the end, we added a comparison table of Slovene alphabet and Hangeul. 
In addition, we proposed to change the name of the guidelines into "Korean Orthography of Foreign Words" as a solution to the arguments on the distinction between loanwords and foreign words, and its scope. Since the users of KOL are Koreans, and the guidelines have to make Koreans spell foreign words consistently, we suggested that guidelines be based firstly on Korean phonological system and orthography. At the same time, the pronunciation in the source language should also be reflected at its maximum. The table below is a comparison table of the Slovene alphabet and Hangeul as a summary of detailed guidelines for Slovene.

Table 6: Comparison table of Abeceda and Hangeul for Korean orthography of Slovene words

\begin{tabular}{lll}
\hline \multirow{3}{*}{ Abeceda } & \multicolumn{1}{l}{ Hangeul } \\
\cline { 2 - 3 } & $\begin{array}{l}\text { before } \\
\text { a vowel }\end{array}$ & $\begin{array}{l}\text { before a } \\
\text { consonant, } \\
\text { final position }\end{array}$ \\
\hline
\end{tabular}

\section{Consonants}

B

C

Č

D

F

G

$\mathrm{H}$

J

K

$\mathrm{L}$

M

N

P

R

S

Š

T
ㅂ

ㅂ, 브, 트

쯔

치

드, 트

프

그, 크

흐

X

ᄀ. 그, 크

ㄹ, ᄅᄅ 우, ᄅ

므, ㅁ

ᄂ

II

ㄹ

人

O, ᄂ

ㅂ, 프

어르, 르

즈, 스

슈, 시

트 bled 블레트, dobro 도브로, občina 옵치나,

pogreb 포그레프

cesta 쩨스타, Logatec 로가테쯔

čokolada 초콜라다, točka 토치카,

Zupančič 주판치치

delo 델로, vrednost 브레드노스트, grad 그라트

fakulteta 파쿨테타, šef 셰프

gibanica 기바니짜, igra 이그라, bog 보크

hrana 흐라나, uspeh 우스페흐

jagoda 야고다, postojna 포스토이나,

kranj 크란

kava 카바, akcija 악찌야, kdo 그도,

Kamnik 캄니크

levo 레보, ljubljana 류블랴나, bolha 보우하,

hotel 호텔, Pekel 페케우

moški 모슈키, mnog 므노그, sejem 세옘

narava 나라바, banka 방카, zakon 자콘

pošta 포슈타, čipka 칩카, lep 레프

roza 로자, torba 토르바, smrt 스머르트, sir 시르

Slovenija 슬로베니야, desno 데스노,

glasba 글라즈바, avtobus 아우토부스

šef 셰프, številka 슈테빌카, Bekeš 베케시

Tolmin 톨민, avto 아우토, list 리스트 


\begin{tabular}{llll}
\hline & \multicolumn{2}{l}{ Hangeul } & \\
\cline { 2 - 3 } Abeceda & $\begin{array}{l}\text { before } \\
\text { a vowel }\end{array}$ & $\begin{array}{l}\text { before } \begin{array}{l}\text { consonant, } \\
\text { final position }\end{array} \\
\text { Orthography examples }\end{array}$ \\
\hline Z & ㅂ & 우 & voda 보다, nov 노우 \\
Ž & & 스 & zvezda 즈베즈다, Iztok 이스토크, Janez 야네스 \\
\hline Vowels & 즈, 시 & žena 제나, dežnik 데주니크, mož 모시 \\
\hline A & 아 & & ananas 아나나스 \\
E & 에 & & evro 에우로 \\
I & 이 & & ime 이메 \\
O & 오 & okno 오크노 \\
$U$ & 우 & ura 우라 \\
\hline
\end{tabular}

※ When a vowel follows after $\mathrm{lj}, \mathrm{nj}, \mathrm{s}, \mathrm{j}$, it is written together with the vowel as one syllable '리, 니, 시, 이', and refer to the detailed guidelines.

We followed the Korean phonological and orthography system except for the sound of Slovene letter $c$, and propose to use a tense sound 及x for $c$ instead of ᄎ although it is not allowed to use a tense sound in present KOL. The reasons are, first, that both $c$ and 及 have same IPA sound [ts], secondly, that we can reflect the original pronunciation at its maximum, thirdly, that there were already exceptions with loanwords from some other languages, and lastly, that there is a movement that the guidelines should be reviewed in case of tense sounds for languages from the Eastern European countries.

There are more and more exchanges between Korea and Slovenia nowadays, and the popularity of Korean Studies at the Department of Asian studies at the Faculty of Arts, University of Ljubljana is increasing. This suggests that Korean orthography of Slovene is indispensable not only to Koreans who want to share their work and experience in Slovenia, but also to Slovenes who want to know how to write their names in Korean when they start studying Korean and other proper nouns later on to introduce their culture and society to Korean people in Korea. This study is the first step to discuss how to spell Slovene words in Korean, and to begin an open discussion on this issue. We are aware that further studies to support our proposal are needed. It would be of our best satisfaction if this research could provide those interested in KOL with the necessary information and call attention for the need of Korean Orthography for Slovene words.

In appendices, please find Korean spellings of the most frequent names, surnames, and largest cities and towns in Slovenia. 


\section{References}

Cho, N.-S., \& Park, S.-B. (2015). A study on the orthographic representation of Russian loanwords in Korean (러시아어 한글 표기법에 대한 제안). Issledovanija po slavjanskim jazykam, 20(2), 2015.10, 197-213.

Choi, J. Y. (2014). Study on Korean Rules of Spelling of Russian Loan Words (러시아어의 한글표기실태 - 학술 논문집을 중심으로). Korean Journal of Russian Language and Literature, 26(4), 2014.12, 139-164.

Greenberg, M. L. (2006). A Short Reference Grammar of Standard Slovene. Durham, North Carolina: SEELRC.

Herrity, P. (2000). Slovene: A Comprehensive Grammar. London, New York: Routledge

I, G. (1935). Oeraeeo Pyogibeop-e daehaya (외래어 표기법에 대하야). HAN-GEUL 3(6), 1935.8, 357-357.

Jang, H.-U. (2002). Problèmes de la notation actuelle du français en coréen et quelques proposition (불어의 한글 표기상 문제점과 개선안). Societe Coreenne d'Enseignement de Langue et Litterature Francaises, 13, 2002.5, 1-17.

Jung, J.-Y. (2017). Hangeul Notation on Dutch Words in Korean (외래어 표기법 속네덜란드어의 한글 표기법). HAN-GEUL, (317), 2017.9, 211-238.

Kim, J.-W. (2008). Korean Orthography of Loanwords and Romanization of Korean From the Viewpoint of Translation (번역의 관점에서 본 외래어 표기법과 로마자 표기법). The Journal of Translation Studies, 9(2), 2008.06, 67-93.

Lečič, R. (2012). Basic grammar of the slovene language, language manual. Cerkno: Gaya d.o.o.

Lee, G.-S. (2016). The Transition Process and Acceptance of 'Korean Orthography of Loanwords' by Ministry of Education: With Emphasis on The Earlier Draft Plans and Editing. Materials of Ministry of Education before Enactment of Korean Orthography of Loanwords 문교부의 ‘외래어 표기법' 변천 과정과 수용 양상 - 외래어 표기법 (1986) 제정이전의 문교부안과 편수자료를 중심으로). Korean Studies Quarterly, 39(1), 2016.3, 107-140.

Lee, H. H. B. (1989). Korean Grammar. Oxford: Oxford university press.

Lee, S.-G. (2011). Fundamental Law of languages based on "foreign words notation" Analysis. (국어기본법 근거한 외래어 표기법의 문제). The Korean Language and Literature, (158), 2011.8, 135-181.

Park, K. Ja. (1997). Zur orthographischen Umsetzung des Deutschen ins Koreanische (독일어의한글표기에 관하여), Deutsch als Fremdsprache in Korea, 2, 1997.6, 294-316.

Toporišič, J. (2004). Slovenska slovenica. Maribor: Založba Obzorja d.d.

Yu, K.-S. (2002). Standardizing transliteration of Italian proper names for Korean library catalogs and bibliographic lists 이탈리아인명, 지명의 한글표기. The Journal of Humanities, 5, 2002.2. 15-43.

Ziraldo, I., \& Krofič, J. (2014). Problems of Hangeul Romanization into Slovene. Acta Linguistica Asiatica, 3(3), 71-84. https://doi.org/10.4312/ala.3.3.71-84

National Institute of Korean Language 국립국어원. (n.d.) Retrieved from https://www.korean.go.kr/ National Library of Korea 국립중앙도서관. (n.d.) Retrieved from http://www.nl.go.kr/nl/search/search.jsp?all=on\&topF1=title_author\&kwd=들온말 적는 법 
National Law Information center 국가법령정보센터. (n.d.). Retrieved from

http://www.law.go.kr/법령/국어심의회규정/(01977,19641110)

Slovene alphabet and pronunciation (n.d.). Retrieved from http://slovlit.ff.uni-lj.si/sft/alphabet.htm

The most frequent Slovene first names (2018). Retrieved from

https://www.stat.si/ImenaRojstva/sl/FirstNames

The most frequent Slovene family names (2018). Retrieved from

https://www.stat.si/ImenaRojstva/sl/FamiliyNames

Največja slovenska mesta po velikosti [The biggest cities in Slovenia] (2007-2019). Retrieved from http://kraji.eu/thematic page/najvecja slovenska mesta po velikosti/slovenija/slo

\section{Abbreviation and Symbols}

C consonant

IPA International Phonetic Alphabet

KOL Korean Orthography of Loanword

$\mathrm{V}$ vowel

$>$ / / read as

* incorrect form 


\section{Appendix 1}

The most frequent Slovene personal names spelled in Korean based on our proposal to spell in Hangeul ${ }^{52}$

\begin{tabular}{llllllll}
\hline Male & \multicolumn{7}{c}{ Female } \\
\hline No. Names & $\begin{array}{l}\text { Number of } \\
\text { names }\end{array}$ & $\begin{array}{c}\text { Names } \\
\text { spelled } \\
\text { Korean }\end{array}$ & in No. Names & $\begin{array}{l}\text { Number of } \\
\text { names }\end{array}$ & $\begin{array}{l}\text { Names } \\
\text { spelled } \\
\text { Koran }\end{array}$ \\
\hline 1 & Franc & 23.554 & 프란쯔 & 1 & Marija & 55.190 & 마리야 \\
2 & Janez & 20.955 & 야네스 & 2 & Ana & 25.463 & 아나 \\
3 & Ivan & 17.406 & 이반 & 3 & Maja & 13.445 & 마야 \\
4 & Anton & 17.228 & 안톤 & 4 & Irena & 12.099 & 이레나 \\
5 & Marko & 17.149 & 마르코 & 5 & Mojca & 11.302 & 모이짜 \\
6 & Andrej & 16.745 & 안드레이 & 6 & Mateja & 10.370 & 마테야 \\
7 & Jožef & 15.198 & 요제프 & 7 & Nina & 10.257 & 니나 \\
8 & Jože & 14.063 & 요제 & 8 & Nataša & 10.035 & 나타샤 \\
9 & Luka & 12.508 & 루카 & 9 & Andreja & 9.350 & 안드레야 \\
10 & Peter & 12.220 & 페테르 & 10 & Barbara & 9.325 & 바르바라 \\
\hline
\end{tabular}

\section{Appendix 2}

The most frequent Slovene family names spelled in Korean based on our proposal to spell in Hangeul ${ }^{53}$

\begin{tabular}{llll}
\hline No. & Family names & Number of family names & Family names spelled in Korean \\
\hline 1 & Novak & 10.999 & 노바크 \\
2 & Horvat & 9.496 & 호르바트 \\
3 & Kovačič & 5.544 & 코바치치 \\
4 & Krajnc & 5.476 & 크라인쯔 \\
5 & Zupančič & 4.999 & 주판치치 \\
6 & Potočnik & 4.689 & 포토치니크 \\
7 & Kovač & 4.623 & 코바치 \\
8 & Mlakar & 3.899 & 믈라카르 \\
9 & Kos & 3.838 & 코스 \\
10 & Vidmar & 3.809 & 비드마르 \\
\hline
\end{tabular}

\footnotetext{
${ }^{52}$ Source retrieved January 1, 2018 from SURS https://www.stat.si/ImenaRojstva/sl/FirstNames

${ }^{53}$ Source retrieved January 1, 2018 from SURS https://www.stat.si/ImenaRojstva/sl/FamiliyNames
} 


\section{Appendix 3}

Slovene city names spelled in Korean based on our proposal to spell in Hangeul ${ }^{54}$

\begin{tabular}{|c|c|c|c|c|}
\hline No. & City names & Population & $\begin{array}{l}\text { City names already in } \\
\text { orthography examples }\end{array}$ & $\begin{array}{l}\text { City names which are not in } \\
\text { orthography examples and } \\
\text { spelled in Korean }\end{array}$ \\
\hline 1 & Ljubljana & 280.940 & 류블랴나 & \\
\hline 2 & Maribor & 95.171 & 마리보르 & \\
\hline 3 & Celje & 37.520 & 첼레 & 쩰례55 \\
\hline 4 & Kranj & 36.874 & 크란 & \\
\hline 5 & Velenje & 25.456 & & 벨레녜 \\
\hline 6 & Koper & 24.996 & & 코페르 \\
\hline 7 & Novo mesto & 23.341 & 노보메스토 & \\
\hline 8 & Ptuj & 18.164 & 프투이 & \\
\hline 9 & Trbovlje & 15.163 & & 터르보울례 \\
\hline 10 & Kamnik & 13.644 & & 캄니크 \\
\hline 11 & Jesenice & 13.440 & & 예세니쩨 \\
\hline 12 & Nova Gorica & 13.178 & & 노바고리짜 \\
\hline 13 & Domžale & 12.406 & & 돔잘레 \\
\hline 14 & Škofja Loka & 11.969 & 슈코퍄로카 & \\
\hline 15 & $\begin{array}{l}\text { Murska } \\
\text { Sobota }\end{array}$ & 11.614 & 무르스카소보타 & \\
\hline 16 & Izola & 11.223 & & 이졸라 \\
\hline 17 & Postojna & 9.183 & 포스토이나 & \\
\hline 18 & Logatec & 8.942 & & 로가테쯔 \\
\hline 19 & Kočevje & 8.672 & 코체볘 & 코체우예56 \\
\hline 20 & Vrhnika & 8.413 & & 버르흐니카 \\
\hline
\end{tabular}

\footnotetext{
54 Source retrieved January 1, 2018 from http://kraji.eu/thematic page/najvecja slovenska mesta po velikosti/slovenija/slo ${ }^{55}$ We propose to amend the Korean orthography of this word from 첼레 into 쩰례. ${ }^{56}$ We propose to amend the Korean orthography of this word from 코체볘 into 코체우예.
} 